\title{
Impact Election Violence on Socio-Economic Situation in Africa: A Case of Kenya
}

\author{
Josephine Kagwiria Kirimi \\ School of Education, Mount Kenya University \\ joskirimi@yahoo.com
}

Christina N. Njuguna

School of Education, Mount Kenya University

cmatheru@gmail.com

\section{Doi:10.5901/mjss.2014.v5n5p}

\begin{abstract}
It is no doubt that violence or war disrupts not only the social, economic, religious dimensions of life but also the education of the community. Violence leads to deaths, destruction of property and displacement of people. It is very hard for children in war torn countries/places to access education due to insecurity, displacement and trauma. This paper endeavours an understanding of the socio-economic situation in Kenya in the wake of election violence.
\end{abstract}

Keywords: Education, Economy, Violence, Politics, Governance, Election

\section{Introduction}

Since independence in 1963, education in Kenya has been regarded as the single most important vehicle for promotion of national unity. Through education, pupils from different ethnic and socio-cultural backgrounds are made to recognize and appreciate unity in diversity of all the people of Kenya. The ultimate goal in forging national consciousness through education is to minimize the impact of ethnicity in people's minds, by enabling them to live peacefully and cooperatively thereby using their varied talents for the enrichment of national life as a unity whole. No education will be worthwhile unless the educated persons can respond to the spirit of national unity which transcends narrower ethnic loyalties. (ROK, 1990). This effort has greatly been hampered by the political status of the Kenyan community since December 2007 when the country was threatened to be torn apart by post election violence (PEV).

\section{Root Causes of Political Violence and Oppression}

Cases of violence during electioneering times in Kenya have many root courses. The Commission of Inquiry into Post Election Violence of 2007/2008 (CIPEV) enumerates and discusses how deep these roots of election are. These factors demonstrate how and why violence has become a way of life in Kenya, a country once known for peace, prosperity, and its potential for development.

CIPEV report shows that the first is the growing politicization and proliferation of violence in Kenya over the years, specifically the institutionalization of violence following the legalization of multi-party democracy in 1991. Over time, this deliberate use of violence by politicians to obtain power since the early 1990s, plus the decision not to punish perpetrators has led to a culture of impunity and a constant escalation of violence. This, in turn, has caused a further diffusion of violence in the country, which now is largely outside of the control of the State and its security agencies. Thus, violence has become a factor not just of elections but in everyday life. What this means in practice is that violence is widespread and can be tapped for a variety of reasons, including but not exclusively to win elections (CIPEV, n.d. 22).

Second is the growing power and personalization of power around the Presidency. This has had a twofold impact. First, it has given rise to the view among politicians and the general public that it is essential for the ethnic group from which they come to win the Presidency in order to ensure access to state resources and goods. Second it also has led to a deliberate denudation of the authority and legitimacy of other oversight institutions that could check abuses of power and corruption and provide some accountability, and at the same time be seen by the public as neutral arbiters with respect to contentious issues, such as disputed elections results. As a result, in many respects the state agencies are not 
seen as legitimate (CIPEV, n.d. 23).

Third, is a feeling among certain ethnic groups of historical marginalization, arising from perceived inequities concerning the allocation of land and other national resources as well as access to public goods and services. This feeling has been tapped by politicians to articulate grievances about historical injustices which resonate with certain sections of the public. This has created an underlying climate of tension and hate, and the potential for violence, waiting to be ignited and to explode.

Fourth is the increasing problem of a growing population of poor, unemployed and youth, educated and uneducated, who agree to join militias and organized gangs. These gangs have been alleged to intersect with parts of the Government and the security forces. These groups now have become "shadow governments" in the slums and even in other parts of the country and have been used by politicians to attack their opponents; to secure their own security, and to gain power. Furthermore, these proliferating militias also are said sometimes to dovetail with the State and its security apparatus thereby not only reducing the State's capacity to control the violence but also increasingly threatening the integrity of the State and the nation. This underlying endemic situation has created a climate where violence is increasingly likely to be used and where its use is increasingly unlikely to be checked.

\section{The Use of Political Violence}

According to CIPEV report, violence was part and parcel of the colonial state, which used it to ensure control in Kenya. After independence, President Jomo Kenyatta used both the carrot and the stick to maintain power, with the use of violence mainly concentrated in the hands of the State, rather than outside of it. Opposition parties were subjected to political harassment and those individuals who refused to support the status quo experienced various types of repression and even detention without trial. Rallies, by students and others, were dispersed by the GSU using force. At the same time, individual members of the opposition were weaned back to the fold through appointments to Government positions, and allocations of land as well as provision of other perks.

For a variety of reasons, repression under Kenya's second President, Daniel arap Moi, became more draconian. First he did not start off with the same array of resources (e.g. land, civil service jobs, and a buoyant coffee boom) available to Kenyatta to reward his supporters and the general public. Second, in 1982, he experienced an attempted coup against him. This followed an unsuccessful attempt to keep him from becoming the President. For both reasons and perhaps for others, violence, including detentions without trial and the routine torture of perceived and real dissenters, became institutionalized early on under Moi's rule. This in turn generated a groundswell of dissent against his rule by a growing opposition movement, including politicians, lawyers, students, and others from all parts of the country (CIPEV, n.d: 24).

According to CIPEV (n.d), in the period leading up to independence and through to 1964 when KADU was dissolved and its members joined KANU, KADU had campaigned for a federal system of government known by the Swahili name of "majimbo", in part to protect the members of the smaller tribes from the numerical power of the larger ethnic groups such as the Kikuyu and Luo. To consolidate his base after becoming the President, Moi rewarded his supporters, particularly the Kalenjin, through appointments to political offices and with jobs in the public service and the military. Rightly or wrongly, these individuals given these were viewed by President Moi's opponents as not qualified or competent.

As the opposition to Moi's leadership grew over the years, civil society became increasingly vocal and donors increased pressure on him, including through the use of financial sanctions, to democratize. In the end, President Moi very reluctantly agreed to allow multi-party democracy in 1991 and he presided over two multi-party elections during his rule, one in 1992 and another in 1997. Although he agreed to multi-party democracy, President Moi did not accept the idea that through this he might lose the presidency. Thus, it was in this period in the 1990s that violence became institutionalized during presidential and parliamentary elections. Under the amended Constitution, to win the presidency, President Moi needed to win his parliamentary seat, obtain a majority of the votes cast in the country, and receive $25 \%$ of the votes cast in five provinces. In both the presidential and parliamentary elections, the opposition to President Moi and to the then ruling party, KANU, consisted mainly of non-KAMATUSA voters (CIPEV, n.d:25). Various reports covering elections held during this period alleged that high ranking political figures, civil servants, and others close to the heart of the Government organized and used violent gangs to intimidate people in areas of potential opposition support, most of whom were Kikuyu, Luo, Luhya, Kamba, and other groups. In CIPEV report, it is put that:

The strategy was to keep opposition supporters from voting and the means used was to hire gangs in the Rift Valley and elsewhere to kill people and displace individuals from their home areas so that KAMATUSA candidates could win and President Moi could be assured of obtaining $25 \%$ of the vote in five provinces, the majority of the votes cast for 
the President, and the majority of elected Members of Parliament. In short, violence became a means of securing political power and winning elections (CIPEV, n.d:26).

Elections related violence occurred not just in 1992 but also in 1997. In spite of the death and destruction that these methods caused and the reports from NGOs such as the Kenya Human Rights Commission, Human Rights Watch, and two Government Inquiries - the Kiliku Parliamentary Committee and Akiwumu Commission - no one was ever punished for this wanton killing and destruction even though names of perpetrators to be investigated and those "adversely mentioned" were contained in the reports of both Commissions. The Akiwumi Report was not made public until 2002, even though it was published in 1999. CIPEV notes that:

This led to a culture of impunity whereby those who maimed and killed for political ends were never brought to justice. This changed Kenya's political landscape with regard to elections (...) reports implicated politicians as the organizers of the violence and killing for political ends, and noted that the warriors and gangs of youth who took action were both paid and pressed into service. Aside from this youths were sometimes Promised Land and jobs after evicting up country dwellers. However, it is not clear if they got either. A pattern had been established of forming groups and using extra-state violence to obtain political power and of not being punished for it (CIPEV, n.d:26).

Gangs and militias continued to proliferate all over the country, thereby increasing the presence of institutionalized extra-state violence both during and after elections, a pattern that continued to increase up through the 2007 elections, even after President Mwai Kibaki took over power in 2002. (...) Political gangs continued to sell their services of violence on a willing buyer willing seller basis (...) (CIPEV, n.d:26).

As extra state violent gangs began to proliferate and continued to be used by politicians, the political terrain was transformed. Violence trickled down into daily life and the State no longer commanded the monopoly of force it once had in a previous era. As such diffused extra state violence existed all over the country, where it could be called up and tapped at any time, including being used to arbitrate over elections as it has been doing since the early 1990s.

Once the Government itself used both its own and extra state violence for partisan political ends, it lost its legitimacy, was not seen as dispassionate, and consequently has been unable either to maintain peace and security or to reform itself (CIPEV, n.d:26).

\section{The Personalization of Presidential Power and the Deliberate Weakening of Public Institutions}

According to (CIPEV, n.d) power has been personalized around the presidency and this has been increased by changes in the Constitution under each President since independence. Laws are routinely passed to increase executive authority, and those laws seen as being in the way are often changed or even ignored. By 1991, the Constitution had been amended about 32 times. Among the amendments was the insertion of Section $2 \mathrm{~A}$, which made Kenya a de jure one party state until that provision was repealed in 1991. Even following the election of Kibaki in 2002 still rules were ignored within Ministries leading to financial scandals such as Anglo Leasing and others underscoring the once again the fact that the personal power of the President and his close associates trumped the law.

Individuals in various parts of Government whether in the civil service, the judiciary, and even in Parliament, understand that, irrespective of the laws, the executive arm of government determines what happens. Hence, the State is not seen as neutral but as the preserve of those in power.

The above syndrome has had various consequences. The first is a sense of lawlessness that has led to Government institutions and officials being seen as lacking in integrity and autonomy. One result of this in the 2007 election was the perception by sections of the public that Government institutions, and officials, including the judiciary, were not independent of the presidency, were not impartial and lacked integrity. Hence, they were perceived as not able to conduct the election fairly. That public sector institutions were seen as biased and unlikely to follow the rules increased the tendency to violence among members of the public. CIPEV, (n.d :) reports that:

(...) members of the provincial administration and the police also understood that it was sometimes in the interest of their personal survival to follow what they understood to be the directives or inclinations of either the President or MPS in their areas rather than to uphold the law. This led to some officials not following the law themselves, and sections of the provincial administration and security forces even engaging in acts of violence themselves (CIPEV, n.d:26)..

The second is the perception on the part of the public that given the power of the President and the political class everything flows not from laws but from the President's power and personal decisions. This also has led the public to believe a person from their own tribe must be in power, both to secure for them benefits and as a defensive strategy to keep other ethnic groups, should these take over power, from taking jobs, land and entitlements. All of this has led to 
acquisition of presidential power being seen both by politicians and the public as a zero sum game, in which losing is seen as hugely costly and is not accepted.

Hence, there is tendency on the part of a variety of political actors to do anything, including engaging in violence to obtain or retain political power, leading to what one specialist has called a race to the bottom because of a fear of being dominated by other ethnic groups and being subjected to the associated consequences of that. This has created a climate of fear and suspicions which politicians easily exploit and use to mobilize violence (CIPEV, n.d:26).

The attempt to reduce the personal power that had been accumulated by former President Moi initially was the reason opposition forces sought to introduce the post of Prime Minister. This culminated in an informal Memorandum of Understanding (MoU) before the 2002 election between the then opposition coalition under which the coalition agreed to introduce the post of Prime Minister after the election. Once elected, however, President Kibaki reneged on the MoU.

As soon as the MoU was scuttled, a group led by Raila Odinga left the coalition Government. President's Kibaki Government was perceived as being unwilling to abide by its pre-election agreement with its partners and as retreating into an ethnic enclave (...) Even though the MoU was not a legal agreement, the Kibaki Government's turning away from it and removing from government the group of Ministers associated to Odinga had the effect of increasing the polarization of politics along ethnic lines (...) With the ethnic political fault lines clearly drawn after 2005, and the need to win the presidency seen as paramount, tensions began to mount (CIPEV, n.d:30).

\section{Land and Inequality}

Kenya consists of 42 ethnic groups who live in eight provinces. Many areas outside the major cities and towns are relatively homogeneous ethnically. Problems of inequality and marginalization thus are often viewed in ethno geographic terms even though the inequalities between individuals of the same ethnic group are sometimes more pronounced than those between different ethnic groups and geographic areas. The presence of a large number of ethnic groups or inequality per se explains large scale violence. Apart from this, citizens every place are concerned that resources, including land, and services are distributed equitably and are quick to point out inequities.

Constitutionally, individuals may own land in any place in Kenya and in law no part of the country belongs to an ethnic group. Nevertheless, this phenomenon is de facto a characteristic of many areas, particularly as many of the newly created districts since the nineteen nineties have been ethno-specific, leading to the creation of ethnically homogenous effective "native reserves".

This in turn has created the notion of "insiders", who are native to a place and "outsiders" who have migrated there, a notion that has been tapped by aspiring politicians. This raises the question of the balance between group interests and the rights of individuals as entrenched in the Constitution, a problem that also has crept into slums (...) which are now informally divided into ethnically homogeneous zones (CIPEV, n.d:31).

Beyond the above, another issue that looms on the horizon is that some communities have done better than others which are poorer, less well developed, and more marginalized from the mainstream. This in turn has generated feelings of resentment and powerlessness, sentiments that can and have been mobilized violently. Furthermore, there is a large and growing underclass of urban poor who are not landowners and are unlikely ever to be landowners.

The tendency has been to think of Kenya almost exclusively as agrarian and of land issues as paramount even though the number of Kenyans living in urban areas is increasing, a tendency likely to continue (CIPEV, n.d:33).

\section{Unemployed Youth}

Although Kenya's population growth rate has been reduced and is now reportedly down to $3 \%$, it still has an estimated two million youth who are unemployed. Furthermore, between 1992 and 1996, the number of street children increased $300 \%$ in just four years. Many of these initially rootless children who are now adults are the product of displacement by ethnic violence. They have grown up on the streets and are inured to violence, something that is clearly very dangerous. In addition, although many youth speak English, something that has raised their expectations, they have no hope of formal sector employment.

The combination of being rootless, having survived amidst violence, plus their need for an identity and a livelihood makes them ready recruits for violent gangs, which exist all over Kenya and are tapped by politicians, particularly but not exclusively during elections.(...) The gangs are devoid of ideology and operate on a willing buyer willing seller basis. (..) There is also a growing problem of unemployment among youth who are university educated, raising the spectre of whether these individuals will also be ready to engage in violence as well if they are unable to find work.

Violent gangs, consisting mainly of unemployed youth have been mobilized into gangs along ethnic lines. Their 
power, to the point of having become shadow governments in many areas, stems from two sources. First as the main aim of Government in the 1990s was to mobilize political support to gain and maintain political power, a good deal of revenue was spent on patronage rather than on maintaining infrastructure and providing social services. This crumbling as well as a decline in social services and security also paved the way for violent gangs which provided them.

This gave unemployed youth work, albeit within gangs, and made the latter extremely powerful. Over time these gangs operated as Mafioso shakedown gangs, with violence and impunity, as they continue to do. Increasingly, citizens began to ask who was in charge of Kenya, gangs or the Government.

While one might have expected that the police could have dealt with the increase in violent gangs operating as virtual shadow states in so many parts of the country, the Government has been ineffective in dealing with them for several reasons. First, many politicians themselves have used these violent gangs to decimate their opponents, to protect themselves from a dictatorial state in the 1990s, and to gain power then and now. This has itself given gangs a life and the ability to operate without fear of being caught. Second, by the time government was serious about banning the groups, they were large, controlled a number of areas, and continued to operate in spite of the bans. Third, security forces including police often were victims of these gangs themselves and used draconian but ineffective force against them.

\section{Effects of Violence on Education}

\subsection{Massive displacement hurting education in Kenya}

Thousands of Kenyan students did not start new school year since the 27 December 2007 poll results plunged parts of the country into chaos, raising concerns about the effect massive displacement and continued instability had on education. There was massive transfers of teachers all over the affected areas to safer areas leaving schools with shortage of teachers which affected performance. "Many of the teachers in the region are from ethnic communities that have left the Rift Valley in their thousands," Bishop Jackson ole Sapit, who covers eight districts in Kenya's western Rift Valley Province, told IRIN. "Many of those who left told us they would seek transfers to areas where they felt safer, which is likely to cause us great problems in the long term.

Students also left schools due to insecurity moving to safer areas which affected learning, a respondent said," I sent my nephew to the secondary school he attends, but only 10 out of 700 students had reported, so he was sent home again," he added.

\subsection{Insecurity (and distance from school)}

Insecurity and distance from school are 'twin' factors, which were cited by both teachers and pupils as inhibiting their children participation in school. Teachers and children in both urban and periurban areas indicated that distance from school coupled with insecurity in their regions made them hesitate to go to school. This was because the post election violence made the school a key target for the hooligans and protesters alike. The bitter youths chanted slogans such as "No Raila, No school" and in some cases stormed schools and threw children out and teachers out. The school represents the government to these youths and therefore the easiest target for them.

Distance and insecurity in many schools visited erodes parents' confidence in sending their children to school. All schools were closed in January until the politicians declared them open and even then, the teachers and pupils were on various occasions forced out of the schools when the political climate became tense and riots were exhibited. Most parents delayed the bringing the their children's enrolment to school until after the signing of the National Accord in late February whereas some brought them in late March and even early April - these were those parents who had relocated from town/urban centres to their rural homes despite being of the same ethnic community. Because of the lack of political stability, some parents pulled the children out of school when they sensed that insecurity is becoming acute as indicated in the photo below of a deserted school.

\subsection{Abandoned classes due to insecurity}

Parents of children in camps were too scared to send their children to local schools in case they were attacked by rival communities or unruly youths. One camp, in the compound of the district commissioner, had more than 1,800 residents who said none of the displaced children was in school. 


\subsection{Rapid response necessary}

The Kenyan Ministry of Education, with UNICEF and other local partners, such as the Kenya Red Cross Society, prepared a "response and recovery" plan to enable schools to start, even in the camps. "As part of this plan, we conducted rapid assessments and started providing school kits, recreation kits and tents where necessary, so that children could start school within the camps," Noor said.

"Recovery meant measures such as extra tuition later on to enable students to catch up on work they missed, but our immediate priority in this case was provision of educational materials, protection and food for school children," he added. "We had yet to reach many areas and there were logistical difficulties ... we could not force the system."

Temporary schools were set up in camps in the country in particular Nakuru and Eldoret, but in areas where UNICEF and the ministry had not yet arrived, camp officials came up with innovative ways to keep the children occupied. At Mulot Camp in Narok South district, displaced teachers set up makeshift classrooms under trees and in district administration buildings; the camp's school named - somewhat irreverently - Refugee Primary School. "We tried, but we had children from different classes grouped together and we had no chalk, black-boards, books or pens so it was very hard," said Samuel Tureiga, a teacher at the camp in Mulot, with 550 residents, a third children. "We tried to keep the children busy so they could have some stability."

\subsection{Strained School Resources due to Internally Displaced learners}

Teachers, boys and girls mentioned that the internally displaced children had brought in new challenges that the schools are forced to deal with. For instance, all the schools enrolled the children without the normal requirement of bringing a desk, these learners have no uniforms (making them conspicuous) and some have no shoes and come in slippers; the learners often lack full concentration both in class and extra curricula activities. The teachers on the other hand, are forced to guide and sometimes counsel these children despite some of them not being trained. There are also few male guidance and counseling teachers despite the relative parity of the girls and boys displaced.

With four or five pupils to a desk, the average class size at Moto primary school, in the western town of Molo, has jumped from 40 in the last term of 2007 to 80 this year since post-election violence hit the country. Some of the children are sitting on stones and in the process of teaching teachers noticed signs of trauma among older children, some of whom were very withdrawn and uncooperative and no counsellors had been to the camp yet. UNICEF carried out assessments in the region, and worked with provincial authorities to get a clearer picture of how the violence affected children and ensured that education in the region returned to normal as soon as the political situation eases. The violence displaced an estimated 600,000 Kenyans, among them school children going and teachers hence negative impact on education.

\section{Sexual and Gender Based Violence (SGBV)}

Increased cases of sexual and gender based violence, especially rape and forced circumcision, related to the postelection violence were reported. While women and girls were the worst affected, there were cases of men who reported having been sodomised or circumcised. For example, between 24th Dec 2007 and Feb 29th 2008, 322 cases of SGBV were reported at the Nairobi Women's Hospital, while 32 were reported at Moi Teaching and Referral Hospital. This was exacerbated by the fact that there was little recourse for help as services to address issues related to SGBV were not available.

Assessments showed that many SGBV cases remain unreported for fear of reprisals, with few victims receiving any assistance to deal with their trauma. As such, the efforts to respond to SGBV were insufficient to deal with the issues experienced. Though survivors of rape were encouraged to visit health facilities for counseling services and administration of Post-Exposure Prophylaxis (PEP), lack of awareness about the 72 hour window during which the treatment is effective, insecurity or lack of resources to travel to the facilities where these services were being offered could have resulted in an increase in number of infections.

Psychosocial issues arising from the effects of the PEV have been described as the 'silent emergency'. Many people were unable to leave their homes to go to IDP camps or elsewhere as this meant that they had to pass through hostile regions. In terms of healing and recovery, this as more serious long-term implications for post-conflict health and social development than the more widely publicized plight of internally displaced people in the country. 
Experiences of sexual and gender based violence like this were suffered on a massive extent a year ago in Kenya - Kibera Secondary, when Kenya faced the worst political crises since independence: In December 2007 Kenya held its fourth general elections since returning to a multiparty system in 1991. The aftermath of this election brought the country to the brink of civil war. Now - a year later - daily live has more or less returned to normal, the "grand coalition" is in progress and trust in the stability of the political system seems to grow - even if the new government still has to prove that they can handle the upcoming important and not always easy political reforms. Still, women are "paying the price" (CREAW 2008): Sadly, but not unusually in conflict and post conflict times, women faced sexual and gender based violence on a vast scale, the wounds of which will last a long time and in particular Kibera Secondary school. This did not exempt the young girls and boys in the community.

While violence and killings took place on a vast scale during the post-election conflict in Kenya, the focus of this research is on the sexual and gender based violence against women and girls and its impact on education. Sexual and gender-based violence against women and girls has been a feature of virtually all recent violent conflicts, including the conflicts in Sudan/ Darfur, the former Yugoslavia, Rwanda and the Democratic Republic of Congo, especially in the Kivu region. Women and girls face a greatly increased risk of physical and sexual violence; rape and other types of gender based violence seem to be a "rule of war".

Few data are available on the total number and extent of sexual and gender based violence during the postelection conflict period in Kenya; and as in all recent conflicts the total number will remain unknown, not at least due to the fact that most cases remain unreported, because of shame, embarrassment, a lack of awareness on the law and a many other reasons. The Nairobi Women's Hospital Gender Violence Recovery Center, Kenya's pioneer health institution specialized in women's health issues, noted that altogether they attended to over 650 cases of GBV related to the postelection crisis. Between late December 2007 and end of February 2008, they alone treated a total of 443 survivors of (S)GBV of which $80 \%$ were rape/ defilement cases, $9 \%$ were physical assault cases, $7 \%$ were domestic violence cases and $4 \%$ were indecent assault (CREAW, 2008, p 5). Gang rape, about $90 \%$ of the rape cases the hospital faced during the political crisis, is supposed to be the most common type of sexual and gender based violence during conflicts and war-time. But this may relate to the fact, that this type of SGBV is also the sexual offence most people are aware of and for that reason, is the most reported one. The CREAW study on sexual and gender based violence in Kenya's 2007 postelection crisis indicated indecent assault as the most prevalent form of sexual violation even, if such cases were not reported as often as incidences of gang rape because women are not aware of it being a sexual offence and a crime (CREAW, 2008, p. 23).

Other types of SGBV occurred during the post-election crisis included attempted assault, sexual slavery, survival sex or sexual exploitation of women: Women were forced to exchange sex in order to secure their own or their families' lives and livelihoods, to gain access to food, shelter or services. Women who fled from conflict-areas and left their home and properties behind were not more secure. They may be assaulted on the way to refugee camps or even inside them. Not only men from the opposite group, tribe, or guerrilla groups, but also the security forces or security personnel, camp officials or aid workers in refugee camps and sometimes men from outside the camp, who can enter unchecked, were among the perpetrators. Women from minority ethnic groups, unaccompanied young women and girls were mostly at risk and attacked due to their lack of protection. Female heads of households, single women and widows also faced this lack of protection and furthermore the necessity to exchange sex in order for their basic needs. Married women were less vulnerable to external sources of sexual aggression, but they remained vulnerable to violence caused to them by their intimate partners. The marital status of women is an important factor indicating the vulnerability of women and girls during conflict periods, but not the only one: age and the dynamics of the area where they are resident are among the others.

All these experiences of sexual and gender based violence and injustice have different bad and harmful (longterm) effects on women. The women affected by it do not only have to suffer psychological traumas and mental tortures on an immeasurable scale - sadly enough; they may become pregnant due to rape. This forces them to abort their foetuses or deliver a child from their rapist who may have even killed their husbands and families and always live with the stigma of being raped. Dimensions of Sexual and Gender Based Violence in Kenya's Post-Election Crisis March 13, 2009 Christina Siebert:

\section{"My daughter is a survivor of sexual abuse, she became pregnant and miscarried, we know who assaulted her, but she has lost hope that she will find justice." (Daily Nation, 13 March,2009).}

This stigma of unwanted pregnancy or "just" rape may lead to separation or divorce from a husband who might have had to witness his wife being raped. Rape and unwanted pregnancy can also lead to forced unions or marriages (with their rapist) to increase economic support and some sense of safety which then ends up in a cycle of rape and 
violence, unwanted pregnancies, economic dependence and emotional and mental trauma.

Another problem and consequence of sexual and gender based violence are rising incidences of HIVI AIDS and other sexually transmitted diseases. Most of the women missed the 72-hour delay during which they could receive medical protection from HIV/sexually transmitted diseases. The HIV transmission rate is unknown and uncountable: not only that many women may have been infected by their rapists and haven't been tested yet and are now infecting their husbands, some of the women who were raped were HIV positive before that and told their perpetrators, but the latter ignored it and went ahead. So there is a group of people who assaulted others who are HIV positive and therefore have been infected with HIVI AIDS. This is very dangerous because these young men are planning to marry or have wives and so they may also be spreading the virus (Waki Commission 2008: 261ff).

\title{
9. Regional Implications
}

Many women know their attacker and because of this they had not sought medical attention or legal redress; by not reporting it and not getting medical attention they furthermore do not have any medical evidence gathered for legal prosecution of rapists.

The lack of reporting: $82 \%$ of survivors of sexual violence interviewed by the study did not formally report the incidents to the police (CREAW 2008: 33) - is another important aspect of GBV. Barriers to report include the personal level: shame, embarrassment, regarding the issue as a private matter, not defining that what happened as a crime, lack of awareness on the law and understanding of human rights, self blame or fearing blame by others and so on. There are also barriers at the level of the criminal justice system, for example, not knowing how and where to report, gender discrimination and lack of sensitivity contributing to minimal confidence in the way police handle sexual violence cases, fear of the police, and / or the legal process as well as being afraid of no one believing them or thinking that nothing would be done. Some women were even attacked by the police, others knew their perpetrators well, and others again could not identify their rapist - more reasons for not formally reporting. There are limited specific and affordable support services for victims such as legal aid or psycho-social counselling, further reducing the motivation to report the violation. To sum up, most victims reported their attacks to immediate family members, friends or the church, but not to the police, local administration or their husbands.

But the Commission of Inquiry into the Post-Election Violence ("Waki Commission") has highlighted the problem and brought the discussion and the dimensions of sexual and gender based violence against women in the post-conflict period into the mainstream of public attention in Kenya. At the policy level, it has thereby provided an opportunity for these women to bring their plight to the ears of the government. Thus, the opportunity of justice exists, but it may be a long journey.

All this demonstrates the dimensions of sexual and gender based violence during Kenya's 2007 post-election violent crisis. But it should also be noted that violence and inequalities which women face in crises do not exist in a vacuum, but are direct results and reflections of the violence, discrimination and marginalization that women face in times of relative peace. (3) However, there are particular aspects relevant to sexual violence in conflict:

\begin{abstract}
According to Ruth Seifert, sexual violence is not considered to be an "aggressive expression of sexuality" but more a "sexual term of violence": Sexual violence seems to be an inevitable effect of war as compensation of (self-suffered) mortification (Mischkowski 2004). Women's bodies are battlefields upon which wars are being waged; the violence against them is a way of celebrating conquest; sexual abuse and assault are used as strategies of warfare.
\end{abstract}

It is mostly women who are targeted by sexual violation which, therefore, is of a gender-related bias and constitutes an expression of supposedly male dominance and hegemony. Grabber/ Sprung (1999) discuss violence against women in war time as a symbol of excessive masculinity, especially when being related to gangrape. It is also a form of male communication: Rape becomes a symbolic expression of the vilification of the male counterpart to show him his weakness and powerlessness of protecting his wife and children. Women are targeted in violent situations to humiliate their whole communities and their husbands who are often forced to watch the assault. Therefore, considering violence against women it is not only the woman who is attacked but also the men (and even the community) who are targeted.

\section{Impact on the Economy}

The violence in Kenya has had serious economic ramifications throughout East Africa, particularly for the landlocked countries of the Great Lakes region like Uganda, Rwanda, Burundi, and Eastern parts of the Democratic Republic of 
Congo. These countries depend upon Kenyan infrastructural links particularly the port at Mombasa for important imports as well as export routes. Significant shortages of gasoline were reported in Uganda as well as Zanzibar following the post elections violence. Nairobi, 6 February 2008 (IRIN) - Unrest in Kenya threatened humanitarian and commercial operations throughout the Great Lakes region, potentially affecting more than 100 million lives, according to analysts.

Southern Sudan, Uganda, Burundi, Rwanda and the eastern Democratic Republic of Congo (DRC) have experienced shortages of fuel and other essential supplies because of insecurity along the Kenyan section of the Northern Corridor, one of the most important transport routes in Africa. It runs from the Kenyan port of Mombasa westwards through Uganda and the Great Lakes. Among aid agencies, the UN World Food Programme (WFP) faces the greatest challenge, feeding seven million vulnerable people in East Africa and the Great Lakes.

\subsection{Slum-dwellers hit hard by post-election crisis}

The majority of the city's inhabitants live in its sprawling slums and it is this impoverished population, together with tens of thousands of displaced people in western Kenya, that has borne the brunt of the violence and disruption unleashed in the wake of the 27 December presidential and parliamentary elections. On 5 January, numerous UN agencies, NGOs and church groups met to plan how best to tackle the humanitarian problems in these slums, where, even at the best of times, most residents live from day to day, surviving thanks to casual labour or the smallest of retail businesses.

"More than two million people live in slums in Nairobi. All have been affected in one way or another," Ingrid Munro, the managing trustee of JamiiBora Trust, a microfinance organisation with 175,000 members across Kenya, told IRIN on the fringes of the meeting.

\section{Insecurity Left Crops Rotting}

Agriculture declined by $4.7 \%$ pushing the price of Kenya's staple food, maize-meal to more than double. This affected the demand side, but an audit trail shows that the supply side suffered even worse. Agriculture is the bed rock of our economy and the largest employer so many jobs have been lost. Tourism is a key deriver of the economy and it declined by $34.7 \%$. It was the hardest hit. Manufacturing declined and since it was still recovering from the previous year's adverse conditions and it fell to $0.7 \%$ way below the $7.5 \%$ forecast.

Transportation being another major employer because it is labour-intensive recorded a marginal gain of a negligible $0.1 \%$. All this set me thinking how this potential loss of jobs would push more people into already crowded informal settlements, both in the rural and urban areas alike. The other small-scale farmers in the western Kenyan district of Nandi North were not directly affected by the violence that ravaged the country in the past month, but their livelihoods were threatened because markets had become inaccessible.

"My tomatoes rotted in the fields, what we harvested we used to cook, the rest was fed to the chickens and calves because roads to many markets were blocked," Chebet, 46, told IRIN on 31 January. They started hawking their products to schools around their environs which did not fetch them much to compensate the farm implements. The amount of food harvested could not cover the cost inputs neither was it enough for the population especially the internally displaced peoples (IDPs) who were fed by Red Cross. Due to the unrest, the National Cereals and Produce Board of Kenya, in charge of the country's grain reserves, has not yet opened maize-buying centres across the Rift Valley region this year.

According to a January update by the Kenya Food Security Network, which comprised the UN World Food Programme (WFP), USAID, Famine Early Warning System and the government, the unrest had led to an unprecedented decline in food security among normally food-secure farmers as well as the urban poor. Overall, the group said, national food security had dramatically declined in just two weeks following the violence that had resulted in hundreds of deaths, displacement of at least 290,000 people and destruction of livelihoods for hundreds of thousands more. This warranted the NGOs to start feeding the displaced families.

\section{Conclusion}

It is evident from this paper that election related violence have far reaching implications and every effort should be put in place to mitigate them. 


\section{References}

Adelman, C., Jenkins, D. and Kemmis, S. (1977) Rethinking Case Study: Notes from the second Cambridge conference, Cambridge Journal of Education.

Bell, J. (1993) Doing Your Research Project: A Guide for First-Time Researchers in Education and Social Science, Open University Press, Buckingham, Philadelphia.

Collier P, Elliot V.L, Herge H., Reynal M and Sambanis N. (2003) Breaking the Conflict Trap: Civil War and Development Policy (A World Bank Policy Research Report), World Bank and Oxford University Pres, Washington D.C.

Kibuuka P. and Karuggah (2003). Certificate Geography, Oxford University Press Nairobi.

Kombo, D.K. (2005). Sociology of Education, Adprint, Nairobi, Kenya.

Machel G. (1996) The New Impact of Armed Conflict on Children, York. United States.

Mungai, K. (2008): Post Election Emergency Health Response Report on the Systems Logistics Subcommittee, 9th January 2008.

http://www.hennet.or.ke/downloads/1200982238Merged\%20Briefs.pdf. Accessed 06/0808.

Myrum J., Ward J., and Marsh, M. (2008): A Rapid Assessment of Gender-Based Violence during the Post-Election Violence in Kenya. Ibid. Conducted January - February, 2008 Source: http://gtz-rhp.com/blog/wp-content/uploads//2008/03/GBVreportfinalMar7.pdf

Nisbet, J.D and Watt, J. (1980) Case Study. Rediguide 26. University of Nottingham, School of Education.

Orodho J.A (2010) Techniques of Writing Research Proposals and Reports in Education and Social Sciences, Masola Publishers, Nairobi.

Republic of Kenya, (1999), Totally Integrated Quality Education and Training, Nairobi.

UNICEF Kenya (2008): Post-Election Violence Situation Report No. 17, 22nd January 2008.

Utne, B. (2002). Education and Development: A Developing Theme, Springer, U.S.A.

Wafula, C and Orlale, O. Daily Nation, Tuesday November 18, 2008, Cabinet to Take Tough Decision on Waki Report, Nairobi. 